\title{
Blended Learning: Issues Related to Successful Implementation
}

\author{
Dr. Thouqan Saleem Yakoub Masadeh \\ Department of Curriculum \& Instruction, Najran University, KSA
}

\begin{abstract}
This study explores the underlying theoretical principles that provide the basis for the design and implementation of blended learning classes. It discusses how online meetings and face-to-face sessions can be integrated in today's classrooms. Many studies and experiences have been reviewed in accordance with the preparation, implementation and evaluation of blended Learning classes. A summary of collected knowledge shows that blended learning has been favorable in today's educational environment. Most studies show that once infrastructure and technological tools are provided, many problems such as crowded classrooms and students' motivation toward learning will be settled via the utilization of Blended Learning. Moreover, the positive and comfortable Blended Learning environments will change the attitudes of students and teachers toward learning and teaching as time and place of lessons will not be a difficulty for both. However, achieving the benefits of Blended Learning models will not yield their fruits unless reviewing matters of training, planning and legislation are done.
\end{abstract}

Keywords: Blended Learning; Online Learning; Face-to-face Learning; Learning Environment; Traditional Classroom.

\section{Introduction:}

Computers' Greater interactivity, graphics, sound and video have affected nearly every aspect of our life. They helped eLearning to be a popular form of learning. Moreover, developments in the Internet speed and browsers allowed everyone to access different resources resulting in the ability of teachers, learners and educational institutions, by one click, to upload and download various learning materials and assessments. The term Blended Learning has been recently referred to as a combination of modern web-based learning methods, with traditional face-to-face ones. By most standards, blended learning is a mechanism that bridges the old and the new by impacting policy and strategic initiatives in higher education at virtually every level (Moskal, Dziuban \& Hartman, 2013: 15). Thus, blended learning is using two or more instructional delivery methods to impart knowledge and skills to the learner. It For example, delivers theoretical content online or via other electronic media and uses the classroom for hands-on instruction and practical examinations (Lothridge, Fox \& Fynan, 2013: 407). Blended learning as a concept involves the use of new educational methodologies and practices, which emphasize student-centered active learning, in conjunction with more traditional approaches which emphasize a teacher-centered approach that assumes passive learning by students (O'Connor, Mortimer \& Bond, 2011). The environment of Blended Learning allows learners to attend face-to-face learning sessions inside classrooms and meanwhile access learning materials outside classrooms via the use of web technology such as, discussion groups and chat platforms. Therefore, not only does Blended Learning environment encourage learners to socially interact with colleagues and teachers, but it also provides them with time and location flexibility that is not possible in face-to-face education (Eryilmaz, 2015).

Blended Learning, as a teaching method, enables students to take advantage of flexible class schedules, network development, collaborative work with peers, active and reflective learning through the use of technology. It empowers instructors with the ability to connect academically and socially with their students (Villalon \& Rasmussen, 2017). Blended Learning, before being officially adopted by educational institutions, was adopted by interested faculty members in using both online and traditional strategies to improve student learning outcomes. They made a strategic initiative and introduced Blended Learning courses (Graham, 
Woodfield \&Harrison, 2013). Furthermore, Blended Learning is assumed to develop the students' skills needed to live and work in the twenty-first century like for instance, communication, information literacy, creativity and collaboration and develop the ability to use digital technologies for a range of purposes (Zurita, Hasbun, Baloian, \& Jerez, 2015). In brief, Blended Learning has many advantages among which are, increased learning skills, greater access to information, improved satisfaction and learning outcomes, and opportunities both to learn from others and to teach them (Cleveland-Innes \& Wilton, 2018).

On the other hand, the effectiveness of Blended Learning as a teaching approach to acquire important skills depends on the readiness of students to learn in a blended learning environment. In other words, Blended Learning is effective if it improves learners' learning performance and learning efficiency and allows them to interact with their classmates and teachers more conveniently (Birbal, Ramdass \&Harripaul, 2018). In addition, students' attitudes toward and perceptions about, i.e. learning flexibility, study management, technology, online learning, online interaction, and classroom learning can shed light on their readiness for blended learning (Tang \& Chaw, 2013). The relationship between students' achievement and the use of and convenience afforded by blended learning are also decisive in its acceptance in classroom. Students will accept this kind of learning, once they feel that they learn and achieve more effectively and feel that they are wellengaged in their classes (Bidder, Mogindol, Saibin, Andrew, \& Naharu, 2016). To say it differently, its flexibility permits individual institutions and collaborative groups to tailor the concept to maximize its potential while being responsive to a new generation of students. It can also increase opportunities for faculty members to design more effective teaching and learning environments. It can foster a much more reflective student population and extends learning far beyond the boundaries of traditional classrooms (Moskal, Dziuban\& Hartman, 2013).

To sum up, educational institutions are called to change their traditional educational strategies for two main reasons. First, traditional strategies are no longer beneficial in empowering learners to master the most urgent skills of the $21^{\text {st }}$ century. They have failed to meet the individual needs of all students in the class basically due to improper pupil teacher ratio. They can not be adapted to meet the challenge represented in teaching students with physical challenges. They are not fit to meet the challenges put forward by the irregular students because attendance is a must and the evaluation system depends on the annual examination (Lalima \& Dangwal, 2017). Second, the dissemination of Covid-19 pandemic, in the last two years, has proved that such institutions should have alternatives for their traditional and face-to-face educational strategies. it has been a must for them all, all over the world, to vary their teaching and learning strategies and try to use Blended Learning as one form of these alternatives and new learning approaches.

\section{Why Blended Learning}

It is unarguable fact that Blended Learning is not the magical solution for the demerits of education nowadays. Nevertheless, it has proved itself as one of the successful educational methodologies in the last two decades because it, as many researchers and educators argue, works as a means of providing qualitative and active education. It positively affects learners' study achievement than the face to face learning environments. In Blended Learning environments, learners actively cooperate and share knowledge with their peers (Eryilmaz, 2015). Moreover, a learning activity combining Blended Learning with the $21_{\text {st }}$ Century skills may lead to meaningful learning, i.e. the learner is able to relate consciously and deliberately new information to already known ideas and knowledge through relevant prior information (Zurita, Hasbun, Baloian \& Jerez, 2014). Online education integrated in Blended Learning is highly advantageous because it promotes online research, connects the practitioners to the global community, gets huge and authentic resources of knowledge required for professional and academic endeavor, and makes them self-disciplined (Paudal, 2021). If teachers design Blended learning activities that can enhance teaching and learning process in Blended Learning environments, students in schools and out of schools, are likely to perform well in learning activities due to Blended Learning resourceful environment that is accessible anywhere at any time (Machumu, Ghasia \& Musabila, 2018). Furthermore, Blended learning model has a set of advantages for students such as the switch from passive 
learning to active learning by putting learners in situations which compel them to read, speak, listen and think. It also offers learners the opportunity to be either together or apart. It adds a human touch to the teaching through creating a high level of interest, accountability, and real assessment. It enhances individualization, personalization and relevance as the instructor tailors learning content to the unique needs of different audience segments (Kaur, 2013). Some other studies indicated that Blended Learning, as a teaching method, was highly valued by students because it provides easier access to the teaching-learning materials, more efficient and quicker communication with the instructor, better ability to pay attention during classes, and the possibility to better prepare for exam (Szadziewska \& Kujawski, 2017). Likewise, Blended learning facilitates improves learning outcomes, access flexibility and student's satisfaction. It also generates a sense of community and empowers him to use resources effectively (Poon, 2013). Similarly, Blended learning has good potential to challenge students to engage in constructing their learning and application to practice (Smyth, Houghton, Cooney, \& Casey, 2011). At the same time, blended learning is more favorable than pure eLearning and offers many advantages for learners like producing a sense of community or belonging. It can be considered as an efficient approach of distance learning in terms of students' learning experience, studentstudent interaction as well as student-instructor interaction (Tayebinik \& Puteh, 2012). Moreover, it has been proved that transitioning from the traditional learning environment to a blended learning model would be beneficial to students as it allows them to learn at their own pace. It is also beneficial for teachers since it allows them to give additional attention to students where needed on a more direct and pinpointed level (Alijani, Kwun \& Yu, 2014). To conclude, it can be strongly claimed that Blended Learning approach has the power to yield a much more reflective student population and disseminates learning far beyond the boundaries of traditional classrooms.

\section{What Blended Learning needs}

Most of studies conducted to investigate the effect of using Blended Learning as a teaching approach have showed that it is useful and effective in teaching. It is seen as a good platform for linking theory and practice in the teaching-learning process. Educational tools, methods and technologies should be blended altogether to accomplish the expected educational goals. The use of Blended learning in education provides the hope to improve student learning outcomes and make the whole educational process a more positive experience generally for students. However, it can not be used as a panacea for all future teaching and learning problems and difficulties (O’Connor, Mortimer \& Bond, 2011). Certain factors impact using Blended learning and meanwhile have an effect on students' behavioral intention to use it. At the top of these factors come the individual psychological factors such as performance and effort expectancy. Organizational factors such as facilitation conditions are not of less importance. Whereas, Social factors, such as social influence, significantly affect students' behavioral intention to use blended learning (Azizi, Roozbahani \& Khatony, 2020). Successful Blended Learning implementation requires successful implementation and use of eLearning in addition to face-to-face learning. Deep analysis of learning objectives should take place at first, followed by the didactic potential that can be transferred to learners via the use of information technology tools. Moreover, planning and developing effective eLearning courses should account for the basic components of teacher's activities such as presentation of educational material, practice, and feedback (Shurygin \& Sabirova, 2017). Adoption of Blended Learning environments demands building on the institution's identity and strengths; and the curricular, pedagogical and technological opportunities. In addition, it needs creating appropriate ecologies for faculty to design/redesign and offer courses that get the best from face-to-face and virtual learning environments (Galvis, 2018). Moreover, key challenges like, ways of facilitating flexibility, facilitating interaction, facilitating students' learning process, and fostering an affective learning climate should be settled before the utilization of Blended Learning in the educational institutions (Boelens, Wever \& Voet, 2017). Other challenges that should be overcome include unstable internet connection, lack of necessary devices/technologies, lack of motivation for self-regulated learning, lack of interaction between facilitators and students, and lack of proper assessment strategies (Al-Amin, Jahan \& Rabbi, 2021). Time management and 
self-discipline in completing the online portion are also believed to be two main continual challenges. Therefore, instructors need to help keep students on track via email reminders, planned pacing of activities, and scheduled deadlines (Shand \& Farrelly, 2018).

Teachers' beliefs about Blended learning are important, too. Some teachers describe it as a burden, because of the increased workload and time devotion, lack of pedagogical and technical skills to conduct Blending Learning and difficulty in finding the right blend between face-to-face and online learning, (Ma'arop \& Embi, 2016). Furthermore, they do not accept Blended Learning because they actually lack the required knowledge and skills to mix the right blending in teaching and learning (Krasnova \& Shurygin, 2019). Blended learning will not fulfill its promise of better learning unless teachers are encouraged to re-think and redesign courses that afford students more, and different learning experiences than those offered by either online or classroom alone (Jeffrey, Milne, Suddaby \& Higgins, 2014). Other barriers for implementing effective Blended Learning classes include lack of time, costs, and lack of qualified teachers, but easy access to online information and advances in technology might resolve these limitations (Khalil, Abdel Meguid, \& Elkhider, 2018). Along with the changes in the roles of teachers and students, Blended Learning can be both beneficial and challengeable, not only for both of them, but also for institutions, educational technologies and the educational approach itself. Better trained teachers can make learners more motivated, autonomous, disciplined and committed. Thus, teachers increasingly need to be proactive and constantly seeking knowledge about new methods, technologies, and tools applicable to the Blended Learning modality (Carmona \& Irgang, 2020)

\section{Models of Blended Learning}

Implementing successful Blended Learning needs building an environment where learners can participate in many learning activities, whether formal or informal. Baldwin-Evans (2006) proposes these eight steps to build an overall structure of Blended Learning:

Step 1: Ensure the learners' readiness to experience learning in a blended setting because most learners need some guidance about how technology can assist them.

Step 2: Use presentation to relate, dramatize, or otherwise disseminate information to learners, making use of verbal or written information and/or visual symbols to convey material quickly.

Step 3: Use demonstration to show the learners how to do a task as well as show why, when, and where it is done, i.e. try to clearly illustrate the idea, concept, principle or procedure to the learner.

Step 4: Through practice allow the learners to build their skills and become more assured in applying and reapplying their newly acquired skills in a life-like situation.

Step 5: Through assessment or testing try to provide this learner with accurate feedback about their understanding of the content and instruction.

Step 6: Support and assist learners to increase their performance through the use of several systems, i.e. multimodal learning or performance support that they will use informally following the formal learning events.

Step 7: Use coaching to allow the learners to enhance their learning from real world experience of others. That is, allow the learners to transit their skills from the knowledge level to the experiential level using the tacit support of experienced learners.

Step 8: Allow each learner to fully participate in collaborative activities to solve problems that can increase his success in applying his new skills within the classroom. Use technology because it keeps remote learners in easy contact and allows them to discuss topics that are important to their unique learning requirements.

On the opposite, Jeffrey, Milne, Suddaby \& Higgins (2014) illustrate that engaging students in fully Blended Learning environment can be done through these three steps:

Step 1: Get students' engaged through using curiosity and relevance as primers for getting their attention and through showing teacher enthusiasm, immediacy and an inclusive environment.

Step 2: Maintain students' engagement through clear content structure; clear, unambiguous instructions and guidelines in assessment; challenging and authentic tasks; and timely, elaborated feedback. 
Step 3: Re-engage students via identifying students in danger of dis-engaging or those who have failed to engage via personal contact means.

Whereas, Marin, Santacruz, \& Gómez (2012:5459) proposed a four-step methodology to take advantage of the benefits of Blended Learning as illustrated in figure 1.

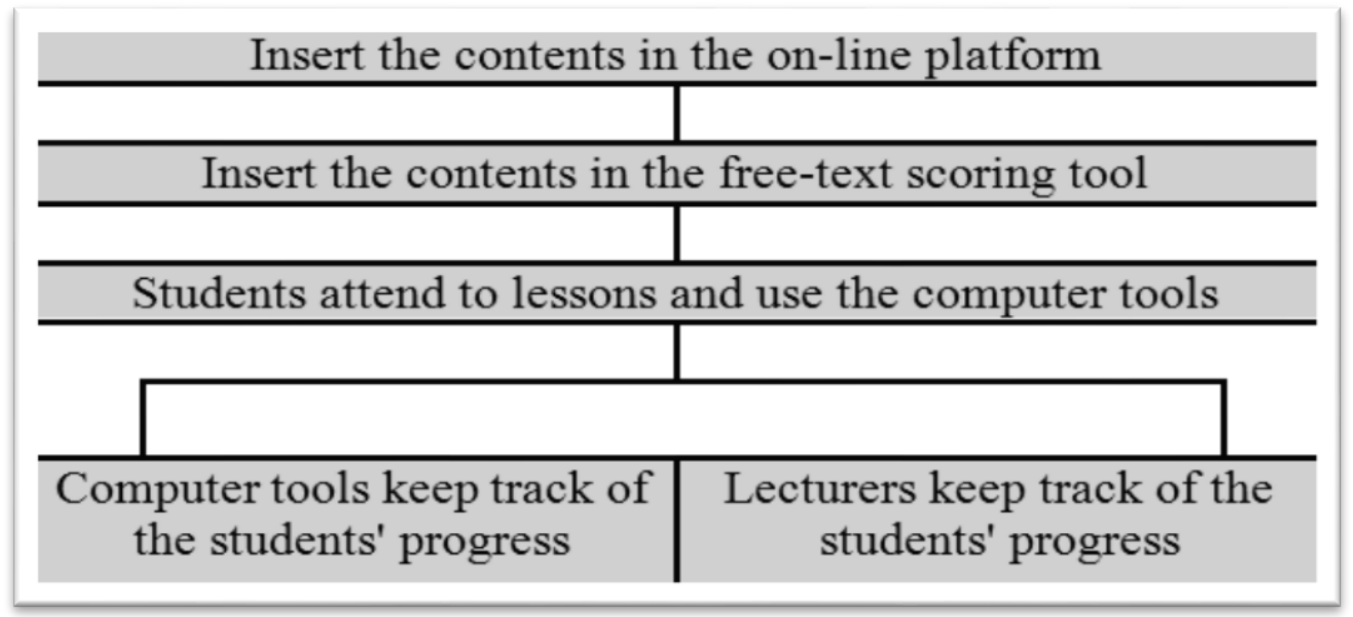

Figure 1: Overview of the proposed methodology

In the first step, teachers should introduce contents in the on-line platform so that students have the possibility to download the digital materials of the course before starting the lesson. Then, they can introduce the contents in the free-text scoring system so as to enable students to get immediate feedback without having to wait for the lecturer to download the works from the on-line platform and evaluate them. After that, students can start using the computer tools. As soon as lectures' contents are introduced in both, on-line platform and free-text scoring tools, students can get a user account to start using them from any computer connected to Internet at any time. Finally, lecturers have to track students and check if some students are not using the computer tools and send them mails automatically to remind them of keeping studying with the computer, too.

On the opposite, Hannon \& Macken (2014:7) presented three models of blended learning, as shown in figure 2 , as a result of their belief that effective blended learning environment should be based on the learning goals and should be aligned with teaching, learning and assessment activities. They also believe that technology integration and use should be very effective.

\begin{tabular}{|c|c|c|}
\hline Model One & Model Two & Model Three \\
\hline $\begin{array}{l}\text { Blended presentation and } \\
\text { interaction } \\
\text { Activity-focused face- to- face } \\
\text { sessions blended with online } \\
\text { resources. } \\
\text { For example, the flipped } \\
\text { curriculum model, combines: } \\
\text { - short lecture podcasts, } \\
\text { online resources, with } \\
\text { - face-to-face } \\
\text { tutorial/seminars for } \\
\text { interaction and presentation }\end{array}$ & $\begin{array}{l}\text { Blended block mode } \\
\text { Combination of: } \\
\text { - intensive face-to-face } \\
\text { sessions as one day or half } \\
\text { days } \\
\text { - weekly online } \\
\text { tutorial/seminars for } \\
\text { activities and interaction } \\
\text { - online content and resources }\end{array}$ & $\begin{array}{l}\text { Predominantly online } \\
\text { Combination of: } \\
\text { - short lecture podcasts, } \\
\text { with online resources and } \\
\text { learning activities } \\
\text { - online or face-to-face } \\
\text { tutorials } \\
\text { - interaction via online or } \\
\text { face-to-face collaboration, } \\
\text { discussion forums and/or } \\
\text { group work }\end{array}$ \\
\hline
\end{tabular}

Figure 2: Models of Blended Learning 
Furthermore, Cleveland-Innes \& Wilton (2018:24-26) claim that creating a successful blended learning environment needs accounting for these principles

Design for open communication and trust: One-on-one interaction between teacher and student as well as communication to the whole group and between students about all matters related to the course and course material is very decisive. Trust in a learning environment can be generated by rules identification, having responsive teachers when needed, and receiving polite and fair treating.

Design for critical reflection and discourse: Students' critical reflection about what they believe to be true is to be highly considered. Hence, it is very important to allow them the opportunity to reflect during the whole course. Hence, it is very important to train them on how to share their ideas carefully and thoughtfully.

Create and sustain a sense of community: Creating and sustaining a sense of community can be through the opportunity to learn together and even teach each other in a peer-teaching setting. Teachers can support the development of healthy community relations by encouraging open communication, setting norms or working together, and ensuring connections among all in the learning group.

Support purposeful inquiry: Passive acceptance and memorization of presented facts and information should be encouraged. In contrast, students should be with the opportunity to practice inquiry-based learning that helps them build knowledge, which brings about deep understanding.

Ensure students sustain collaboration: The need for students to work collaboratively refers not only to new ways of learning and remembering course material, but also to skills required to live and work in a complex, interconnected social and economic world.

Ensure that inquiry moves to resolution: The teacher should follow a systematic and disciplined investigation that moves participants through the inquiry phases until reaching a resolution in a timely manner.

Ensure assessment is congruent with intended learning outcomes: The planned detailed learning outcomes and the designed activities to attain the outcomes should be aligned with the three types of assessment, i.e. self-assessment, peer-assessment, teacher assessment, and mastery assessment.

Another three-phase Blended Learning model, as shown in figure 3, is presented by (Sarkar, Sharma \& Raheja, 2021:415). The model reveals that phase one takes place before the large group session. Students are given a lecture compiled soft and hard copy handouts, versions, reference books to be read before the session, and a PowerPoint presentation. In phase two and during the large group session, four aspects namely: probing for the muddiest points of the pre-session preparation; discussion of the critical concepts of the topic; interactive questions and answers session and feedback; and reflections on the process are included. The last phase takes place after large group session where students revise and reflect on the topic again at home after the session. At the end of the three phases, students sit for a formative assessment.

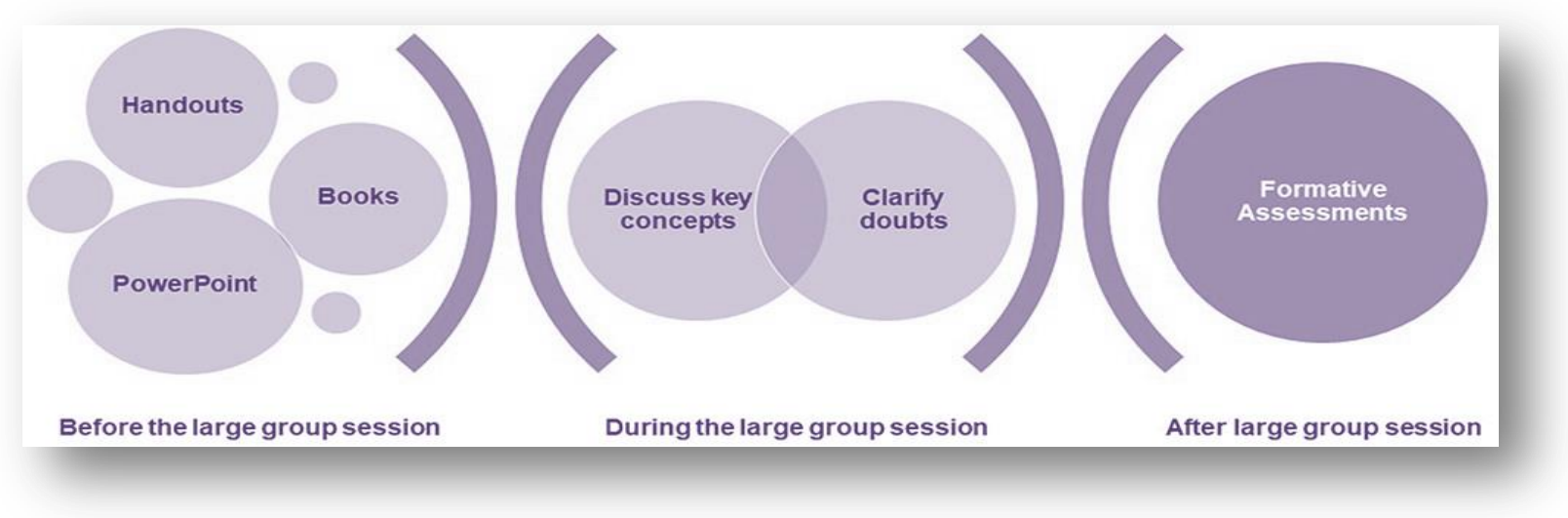

Figure 3: Phased delivery of the blended learning approach

\section{Evaluation of blended learning}

Designing Blended Learning environment is not an easy task for teachers. Many key challenges face them like incorporating flexibility, stimulating interaction, facilitating students' learning processes, and fostering an 
affective learning climate (Boelens, Wever \& Voet, 2017). Evaluating Blended Learning has a set of purposes. For instance, it aims to make a clear picture of how effective it is on students' engagement, how effective the used learning resources are. In other words, it aims to determine the quality of the whole course. Therefore, viewpoints of students, teachers, and administrators are of great importance regarding the course outcomes, and the learner's satisfaction and engagement (Bowyer \& Chambers, 2017). Besides, the accreditation of a blended learning strategy not only depends on the technological aspect of the learning process, but also on people, i.e., students who are engaged in the process and motivated teachers who possess the required knowledge and skills (Al-Ayed \& Al-Tit, 2021). Furthermore, success of Blended learning depends on specific factors like the quality of the course to be taught, the virtual environment where to teach and learn, and to what extent students are prepared to work in their virtual study environment. Attitudes of learners toward implementing the assigned task, their ability to make themselves organized in a given background, and their ability to use all the tools offered by the learning management system are important, too (Hubackova \& Semradova, 2017). Consequently, most studies conducted in the area of stakeholders' perceptions about Blended Learning have proved its efficacy in many fields. Apart from the fact that Blended Learning utilization affects positively attitudes of learners, it can also develop and enhance their knowledge and skills. For instance, the electronic resources provided through blended learning represent a tremendous effect on increasing students' responsibility for their own learning process making it clearer (Aladwanm, Fakhouri, Alawamrah, \& Rababah, 2018). Studies also show that students prefer Blended Learning as a teaching approach though they think that paper-and-pencil exams are more comfortable. Their proficiency in the courses they study is positively correlated with their preferences of Blended Learning (Akbarov, Gönen, \& Aydoğan, 2018). In addition, research has shown that students' positive perceptions toward the use of Blended Learning can have a positive effect on the enhancement of their language skills, autonomous learning and motivation (Bakeer, 2018). One more interesting point is that used technology tools affect the satisfaction of learners and attitudes toward Blended Learning. In addition, Knowledgeable and skillful teachers are more capable of using better teaching strategies required for online teaching (Taghizadeh \& Hajhosseini, 2020). Besides, evaluating the effectiveness of Blended Learning should be carried out in light of the confidence in communication with which it provides learners and meanwhile the development of their responses to the teacher in comparison with what traditional face-to-face classroom can offer. In addition, it can be impactful if it provides the opportunity to explore students' needs and potentials (Zainon \& Yamat, 2021). ELearning adaptability, perceived usefulness, in-time of teacher's response, perceived ease of use and course applicability are also important factors affecting students' satisfaction in using Blended Learning (Zhao \& Yuan, 2010).

On the other part, perceptions and attitudes of teachers are very important and decisive in the successful implementation of any Blended Learning model. As experts and responsible for implementing such teaching model, they point out that problems in internet connection and site restrictions usually prevent them from appreciating online learning. Viewpoints of teachers about the effective Blended Learning environments or models vary. Some of them, for instance believe that there should be strong institutional support to allow them realize the importance of their role and meanwhile the importance of technology in todays' digital world (Cabauatan, Uy, Manalo, \& Castro, 2021). Other teachers believe that success of blended learning implementation demands the existence of policy support, readiness of IT infrastructure and willing teachers to change their viewpoints regarding ICT integration in teaching (Dewi, Ciptayani, Surjono, \& Priyanto, 2018). In addition, some teachers think that individualized instruction needs an understanding of students' needs, varied and individual success criteria, strong relationships with students tied to decision-making that fosters individual achievement and combat low motivation level (Mathews \& Ward, 2019). Rigorous efforts, right attitude, handsome budget and highly motivated teachers and students play significant roles in the effectiveness of Blended Learning (Lalima \& Dangwal, 2017 and Mahmodi \& Moghadam, 2017). Impactful blended Learning also is in need for accurate planning for the educational activities, effective tutoring system, qualitative interactions between teachers and students, the quality of interactions with the teacher and between 
students, in addition to the consideration of students' needs and expectations (Ravioloa, Simoneb, Mauroc, \& Rondonottid, 2021). Furthermore, some studies concluded that successful implementation of Blended Learning depends on the implementation and use of eLearning courses. Before starting blending, i.e. using eLearning, a process of deep analysis of the learning objectives, didactic potential of the new training information technology transfer, and requirements for blended learning should be carried out. The teacher has to be knowledgeable of his activities like for instance, presentation of educational material, practice, and feedback (Shurygin \& Sabirova, 2017).

In conclusion, with a rapid growth of innovation in the use of technologies in education and learning, blended learning can be an effective method in student's education. Most studies conducted to assess the impact and efficacy of Blended Learning agree on the importance of accounting for the viewpoints of both, the students and the teachers. Studying the views of these two parties, we can conclude that factors like: the learning climate, perceived enjoyment, perceived usefulness, system functionality, social interaction, teacher merits, content feature and performance expectation are significantly the most important factors affecting students' satisfaction degree of Blended Learning. However, classroom components, learning functions, engagement strategies (Jeffrey, Milne, \& Suddaby, 2019). orienting students to the software and learning expectations, troubleshooting technical issues, motivating students to fully engage with the software, monitoring students' behavior and learning in the system, providing students with additional instruction in small groups or individually (Amro \& Borup, 2019) were the most important sources of anxiety for teachers with regard to whether they can implement effective and successful Blended Learning classes.

\section{Conclusion}

Blended Learning as a concept and a teaching model has been very popular in the technologically developed countries. In the developing countries it is still new and education regimes have not completely accredited it in their institutions because of some reasons among which is the lack of technology experts, insufficient infrastructure and the educational environment. With the emergence of Covid-19 and its serious effects on people's lives, all developed and developing countries all over the world started calling for an increase in the portion of online learning in the educational process. This call, of course, is not a critic challenge for developed countries, while it is so for the developing ones. Therefore, stakeholders before taking decision to adopt this mode of teaching and learning seek knowledge about its benefits and effectiveness of learning is the first priority of teaching and learning. Hence, this paper has reflected on the varied experience about the delivery of blended learning in different places. It tries to address the need of teachers and students for a teaching and learning environment that sufficiently reflects their realities, provides them with a rich structure in resources and multiple opportunities for real-time and differed dialog between learners as well as between learners and faculty. The reflections it has been concluded are assumed to be helpful for educators who wish to conduct blended Learning classes. They have shown that there should be a balance between the aims of administration, faculty limits and learner needs. Meanwhile, it sheds light on the requirements for structure and dialogue in a workable teaching-learning environment.

\section{References}

1. Akbarov, A.; Gönen, K.; \& Aydoğan, H. (2018). Students' Attitudes toward Blended Learning In EFL context, Acta Didactica Napocensia, 11(1): 61-68. http://padi.psiedu.ubbcluj.ro/adn/article_11_1_5.pdf

2. Aladwanm, F.; Fakhouri, H.; Alawamrah, A.; \& Rababah, O. (2018). Students Attitudes toward Blended Learning among students of the University of Jordan, Modern Applied Science, 12(12). DOI: $10.5539 /$ mas.v12n12p217

3. Al-Amin, M.; Jahan, I.; Rabbi, M.F.; \& Islam, U.N. (2021). Can Blended Learning be the New-Normal in Higher Education of Bangladesh? International Journal of Educational Research Review, 6(4): 306-317. https://dergipark.org.tr/en/pub/ijere/issue/64800/944932 
4. Al-Ayed, S. \& Al-Tit, A. (2021). Factors Affecting the Adoption of Blended Learning Strategy, International Journal of Data and Network Science, 5(3): 267-274. http://www.growingscience.com/ijds/Vol5/ijdns_2021_34.pdf

5. Alijani, G. S; Kwun, O. \& Yu, Y. (2014). Effectiveness of Blended Learning in KIPP New Orleans' schools, Academy of Educational Leadership Journal, 18(2). https://www.proquest.com/docview/1645850304/fulltextPDF/5B5AC78859CF4B0APQ/1 ?accountid=399 $\underline{66}$

6. Amro, F. \& Borup, J. (2019). Exploring Blended Teacher Roles and Obstacles to Success When Using Personalized Learning Software, Journal of Online Learning Research, 5(3): 229-250. https://files.eric.ed.gov/fulltext/EJ1241760.pdf

7. Azizi, S.A.; Roozbahani, N. \& Khatony, A. (2020). Factors Affecting the Acceptance of Blended Learning in Medical Education: Application of UTAUT2 Model, BMC Medical Education, 20: 20:367. https://doi.org/10.1186/s12909-020-02302-2

8. Bakeer, A.M. (2018). Students' Attitudes towards Implementing Blended Learning in Teaching English in Higher Education Institutions: A Case of Al-Quds Open University, International Journal of Humanities and Social Science, 8(6). https://www.ijhssnet.com/journals/Vol_8_No_6_June_2018/15.pdf

9. Bidder, C.; Mogindol, S.H.; Saibin T.C.; Andrew, S.A. \& Naharu, N. (2016). Students' Perceptions of Blended Learning and Achievement. In: Luaran J., Sardi J., Aziz A., Alias N. (eds) Envisioning the Future of Online Learning. Springer, Singapore. https://doi.org/10.1007/978-981-10-0954-9_19

10. Birbal, D.; Ramdass, M. \& Harripaul, C. (2018). Student Teachers' Attitudes towards Blended Learning, Journal of Education and Human Development, $7(2):$ 9-26. http://jehdnet.com/journals/jehd/Vol_7_No_2_June_2018/2.pdf

11. Boelens, R.; De Wever, B.; \& Voet, M. (2017). Four Key Challenges to the Design of Blended Learning: A systematic Literature Review, Educational Research Review, 22:1-18. https://doi.org/10.1016/j.edurev.2017.06.001

12. Bowyer, J. \& Chambers, L. (2017). Evaluating Blended Learning: Bringing the Elements Together, Research Matters, 23. https://www.cambridgeassessment.org.uk/Images/375446-evaluating-blendedlearning-bringing-the-elements-together.pdf

13. Cabauatan, R.R.; Uy, C.; Manalo, R.A. ;\& Castro, B. (2021). Factors Affecting Intention to Use Blended Learning Approach in the Tertiary Level: A Quantitative Approach, Higher Education for the Future, 8(2). https://doi.org/10.1177/23476311211011934

14. Carmona, L.J. \& Irgang, L.F. (2020). Challenges on Teaching of Management through Blended Education, Pensamento Contemporâneo em Administração, 14(1). DOI: https://doi.org/10.12712/rpca.v14i1.40632

15. Cleveland-Innes, M. \& Wilton, D. (2018). Guide to Blended Learning, Commonwealth of Learning: Canada. https://oer4nosp.col.org/id/eprint/35/1/Cleveland-Innes-Wilton_Guide-to-Blended-Learning.pdf

16. Dewi, K.C. ; Ciptayani, P.I.; Surjono, H.D. ; Priyanto. (2018). Critical Success Factor for Implementing Vocational Blended Learning, Journal of Physics: Conference Series. https://iopscience.iop.org/article/10.1088/1742-6596/953/1/012086/pdf

17. Eryilmaz, M. (2015). The Effectiveness of Blended Learning Environments, Contemporary Issues in Education Research, 8(4). https://files.eric.ed.gov/fulltext/EJ1077330.pdf

18. Galvis, Á.H. (2018). Supporting Decision-Making Processes on Blended Learning in Higher Education: Literature and Good Practices Review, International Journal of Educational Technology in Higher Education, 15, 15:25. https://doi.org/10.1186/s41239-018-0106-1

19. Graham, C. R.; Woodfield, W. \& Harrison, J. B. (2013). A Framework for Institutional Adoption and Implementation of Blended Learning in Higher Education, The Internet and Higher Education, 18: 4-14. https://doi.org/10.1016/j.iheduc.2012.09.003 
20. Hannon, J., \& Macken, C. (2014). Blended and Online Curriculum Design Toolkit. La Trobe University, Future Ready Toolkit v4. https://www.latrobe.edu.au/_data/assets/pdf_file/0006/602178/Blendedlearning-Toolkit-v4.pdf

21. Hubackova, S. \& Semradova, I. (2017). Evaluation of Blended Learning, Procedia-Social and Behavioral Sciences, 217(5): 551-557. https://doi.org/10.1016/j.sbspro.2016.02.044

22. Jeffrey, L. M.; Milne, J.; Suddaby. G.; \& Higgins, A. (2014). Blended Learning: How Teachers Balance the Blend of Online and Classroom Components. Journal of Information Technology Education: Research, 13: 121-140. http://www.jite.org/documents/Vol13/JITEv13ResearchP121-140Jeffrey0460.pdf

23. Kaur, M. (2013). Blended Learning - Its Challenges and Future, Procedia - Social and Behavioral Sciences, 93: 612 - 617. https://doi.org/10.1016/j.sbspro.2013.09.248

24. Khalil, M.K.; Meguid, E.H.; \& Elkhider, I.E. (2018). Teaching of Anatomical Sciences: A Blended Learning Approach, Clinical anatomy, 31(3): 323-329. https://doi.org/10.1002/ca.23052

25. Krasnova, L., \& Shurygin, V. (2019). Blended Learning of Physics in the Context of the Professional Development of Teachers. International Journal of Emerging Technologies in Learning (IJET), 14(23), 17-32. DOI: http://dx.doi.org/10.3991/ijet.v14i23.11084

26. Lalima \& Dangwal, K.L. (2017). Blended Learning: An Innovative Approach, Universal Journal of Educational Research 5(1): 129-136. https://www.hrpub.org/download/20161230/UJER16-19508256.pdf

27. Lothridge, K.; Fox, J. \& Fynan, E. (2013). Blended Learning: Efficient, Timely and Cost Effective, Australian Journal of Forensic Sciences, $407-416$. http://dx.doi.org/10.1080/00450618.2013.767375

28. Ma'arop, A. H., \& Embi, M. A. (2016). Implementation of Blended Learning in Higher Learning Institutions: A Review of the Literature. International Education Studies, 9(3), 41-52. DOI: https://doi.org/10.5539/ies.v9n3p41

29. Machumu, H.; Ghasia, M. \& Musabila, A. K. (2018). Blended Learning Activities in Blended Learning Environments : Experiences from Mzumbe University, Tanzania. EdMedia + Innovate Learning 2018: proceedings. Amsterdam. https://core.ac.uk/download/pdf/228044568.pdf

30. Mahmodi, M. \& Moghadam, M.J. (2017). Requirements of Using the Blended Educational System from the Viewpoints of the Faculty Members, Interdiscip J Virtual Learn Med Sci, 8(3). http://dx.doi.org/\%2010.5812/ijvlms.10331

31. Marin, D.P.; Santacruz, L.; \& Gómez, M.G. (2012). A Proposal for A Blended Learning Methodology and How to Apply it With University Students, Procedia - Social and Behavioral Sciences 46, 5458 - 5462. DOI:10.1016/j.sbspro.2012.06.457

32. Mathews, A. \& Ward, C. (2019). Effective Practices of Successful Blended Learning Schools, Frontiers in Education Technology, 2(2). http://dx.doi.org/10.22158/fet.v2n2p88

33. Moskal, P.; Dziuban, C. \& Hartman, J. (2013). Blended Learning: A Dangerous Idea? Internet and Higher Education, 18: 15-23. http://dx.doi.org/10.1016/j.iheduc.2012.12.001

34. O’Connor, C.; Mortimer, D. \& Bond, S. (2011). Blended Learning: Issues, Benefits and Challenges, International Journal of Employment Studies (IJES), 9(2). https://eds-b-ebscohostcom.sdl.idm.oclc.org/eds/pdfviewer/pdfviewer?vid=1\&sid=33ee126f-ea3e-4a4c-b8e5d3c6300d4a53\%40sessionmgr103

35. Paudal, P. (2021). Online Education: Benefits, Challenges and Strategies During and After COVID-19 in Higher Education, International Journal on Studies in Education, 3(2): 70-85. DOI: https://doi.org/10.46328/ijonse.32

36. Poon, J. (2013). Blended Learning: An Institutional Approach for Enhancing Students' Learning Experiences, MERLOT Journal of Online Learning and Teaching, 9(2). https://dro.deakin.edu.au/eserv/DU:30057995/poon-blendedlearning-2013.pdf

37. Ravioloa, P.; Simoneb, M.G.; Mauroc, I.; \& Rondonottid, M. (2021). Blended Learning in Online Teaching. Design Strategies and Future Developments, Proceedings of the First Workshop on Technology 
Enhanced Learning Environments for Blended Education (teleXbe2021), January 21-22, 2021, Foggia, Italy. http://ceur-ws.org/Vol-2817/paper22.pdf

38. Sarkar, S.; Sharma, S.; \& Raheja, S. (2021). Implementation of Blended Learning Approach for Improving Anatomy Lectures of Phase I MBBS Students - Learner Satisfaction Survey, Advances in Medical Education and Practice, 12: 413-420. https://doi.org/10.2147/AMEP.S301634

39. Shand, K. \& Farrelly, S.G. (2018). The Art of Blending: Benefits and Challenges of a Blended Course for Preservice Teachers, Journal of Educators Online, 15(1). https://eric.ed.gov/?id=EJ1168949

40. Shurygin, V.Y. \& Sabirova, F.M. (2017). Particularities of blended learning implementation in teaching physics by means of LMS Moodle, Revista ESPACIOS, 38 (40). https://www.revistaespacios.com/a17v38n40/a17v38n40p39.pdf

41. Smyth, S.; Houghton, C.; Cooney, A. \& Casey, D. (2011). Students' Experiences of Blended Learning across a Range of Postgraduate Programmes, Nurse Education Today, 32(4). https://www.sciencedirect.com/science/article/abs/pii/S0260691711001262?via\%3Dihub

42. Szadziewska, A. \& Kujawski, J. (2017). Advantages and Disadvantages of the Blended-Learning Method Used in the Educational Process at the Faculty of Management at the University of Gdansk, in the Opinion of Undergraduate Students, Proceedings of ICERI2017 Conference16th-18th November 2017, Seville, Spain. DOI:10.21125/iceri.2017.1051

43. Taghizadeh, M. \& Hajhosseini, F. (2020). Investigating a Blended Learning Environment: Contribution of Attitude, Interaction, and Quality of Teaching to Satisfaction of Graduate Students of TEFL, The AsiaPacific Education Researcher, 30: 459-469. DOI: https://doi.org/10.1007/s40299-020-00531-z

44. Tang, C.M. \& Chaw, L.Y. (2013). Readiness for Blended Learning: Understanding Attitude of University Students. International Journal of Cyber Society and Education, 6(2): 79-100. http://dx.doi.org/10.7903/ijcse.1086

45. Tayebinik, M. \& Puteh, M. (2012). Blended Learning or E-learning? International Magazine on Advances in Computer Science and Telecommunications, $103-110$. https://papers.ssrn.com/sol3/papers.cfm?abstract_id=2282881

46. Villalon, C. \& Rasmussen, N. (2017). Influence of Instructor's Attitudes, Gender, and Technology Training, National Teacher Education Journal, https://content.ebscohost.com/ContentServer.asp?T=P\&P=AN\&K=128857594\&S=R\&D=ehh\&EbscoCon tent=dGJyMMTo50SeprE40dvuOLCmsEmep7ZSrq24S66WxWXS\&ContentCustomer=dGJyMOzpsEqy qbdOuePfgeyx43zx

47. Zainon, H. \& Yamat, H. (2021). Effects of Blended Learning on Motivating Secondary Students to Learn English Language: A Pilot Study, Journal of English Language Teaching and Applied Linguistics, 3(2). https://al-kindipublisher.com/index.php/jeltal/article/view/1318

48. Zhao G., Yuan S. (2010) Key Factors of Effecting Blended Learning Satisfaction: A Study on Peking University Students. In: Tsang P., Cheung S.K.S., Lee V.S.K., Huang R. (eds) Hybrid Learning. ICHL 2010. Lecture Notes in Computer Science, Vol. 6248. Springer, Berlin, Heidelberg. https://doi.org/10.1007/978-3-642-14657-2_26

49. Zurita G.; Hasbun B.; Baloian N. \& Jerez O. (2015). A Blended Learning Environment for Enhancing Meaningful Learning Using 21st Century Skills. In: Chen G., Kumar V., Kinshuk, Huang R., Kong S. (eds) Emerging Issues in Smart Learning. Lecture Notes in Educational Technology. Springer, Berlin, Heidelberg. https://link-springer-com.sdl.idm.oclc.org/content/pdf/10.1007\%2F978-3-662-44188-6.pdf 